\title{
Romania's participation in FP7 and H2020: a comparative approach in the context of the new EU member countries
}

\author{
DOI: $10.35530 / I T .071 .02 .1813$
}

Romania's participation in FP7 and H2020: a comparative approach in the context of the new EU member countries

The main objective of the paper is to provide a general overview on Romania's ability to attract European funds for research, development and innovation. The paper compares the participation of the former communist countries of Europe in FP7 and H2020. The main conclusions of the analysis are: EU12 presents cumulative participation in the research framework programs far below Western Europe; the productivity of EU12 research staff, measured by the ability to attract European funds, has increased significantly, but there are large gaps between the countries analysed; Romania has seen an improvement in the participation in the two European programs, but remains on the last place in terms of EU contribution per inhabitant.

Keywords: EU funding, H2020, FP7, EU12, Romania

\section{Participarea României la FP7 şi H2020: analiză comparativă în contextul noilor ţări membre UE}

Principalul obiectiv al lucrării este să ofere o perspectivă generală asupra capacităţii României de a atrage fonduri europene pentru cercetare, dezvoltare şi inovare. Lucrarea analizează comparativ participarea ţărilor foste comuniste din Europa la FP7 şi H2020. Principalele concluzii ale analizei sunt: EU12 prezintă cumulat o participare la programele cadru de cercetare mult inferioară Europei de Vest; productivitatea personalului din domeniul cercetării din EU12, măsurată prin capacitatea de a atrage fonduri europene, a crescut semnificativ, dar există decalaje mari între ţările analizate; România a cunoscut o îmbunătătire a participării la cele două programe europene, dar rămâne pe ultimul loc din punctul de vedere al contribuţiei Uniunii Europene pe locuitor.

Cuvinte-cheie: finanțare UE, H2020, FP7, EU12, România

\section{INTRODUCTION}

The main objective of this paper is to present a general view of the Romanian scientific community interest into use the European funds designated for research, development and innovation actions in a regional context. Horizon 2020, the European Union's 8th Framework Programme for Research, is the financial instrument implementing the Innovation Union. It is the programme that has a budget of almost $€ 80$ billion for the seven years of the programme (2014-2020), it is the largest budget from all the Framework programmes.

Horizon 2020 is built on three pillars:

1. Support for Excellent Science: frontier research funded by the European Research Council; networking of existing research infrastructures; mobility grants for all stages of researchers' careers (Marie Skłodowska-Curie actions).

2. Support for Industrial Leadership: projects of great importance for Europe's industrial competitiveness; targeted support of small and medium enterprises (SMEs).
3. Support for research to tackle societal challenges: projects focusing on the priority societal challenges identified by the EU.

In addition, there are four further cross-cutting and supporting measures:

- Spreading Excellence and Widening Participation.

- Science with and for Society.

- Joint Research Centre (JRC).

- European Institute of Innovation and Technology (EIT).

FP 7 was the main instrument of European Union for research funding in Europe during 2007-2013, with a total budget of 53.2 billion euro. It was structured in five components: Cooperation, Ideas, People, Capacities and Nuclear Research.

When performing a comparison between FP7 and H2020 programmes we can easily identify the followings:

- The budget is larger for H2020 with approximately 25 billion euro;

- The components are different, as mentioned above;

- Funding rate for research has increased to $100 \%$ in $\mathrm{H} 2020$ versus $75 \%$ in FP7; 
- Funding rate for Demonstration/Innovation actions has also increase up to $70 \%$ in $\mathrm{H} 2020$ versus $50 \%$ in $\mathrm{FP} 7$, in $\mathrm{H} 2020$ the funding rate can also reach the $100 \%$ for non-profit organization for these types of projects;

- The overhead is fixed for all beneficiaries to $25 \%$ from direct cost

- Time to grant has reduced significantly to 8 months in $\mathrm{H} 2020$, from approx. 12 months in FP7.

In addition, H2020 is more focused on innovation, multidisciplinary projects, and SMEs [1].

This paper is structured as follows: in the first part, the reference literature and the methodology are presented. The second part analysed the former communist countries' participation to FP7 and $\mathrm{H} 2020$ with a special focus on Romania. The work ends with discussions and conclusions.

\section{LITERATURE REFERENCES AND METHODOLOGY}

The limited participation of the new member states to FP7 is highlighted by several publications such as Vught [2], Rauch and Sommer-Ulrich [3] and Galsworthy and McKee [4]. Among the causes mentioned in these studies there are: the quality of research and education establishments, the human, financial, and managerial capacities, the available infrastructure and the salaries level. MoagarPoladian, Folea and Paunica [5] analyse the competitiveness of the EU member countries during FP7 and partially $\mathrm{H} 2020$. They conclude that the new member states are less competitive than EU15 and confirm the causes mentioned by previous studies. Ukrainski et al. [6] evaluates the degree of segregation and integration of the new member states in FP7 and $\mathrm{H} 2020$ with the help of three indices: Index of dissimilarity, Index of isolation and Index of interaction. Their conclusions are that: segregation and isolation increased in $\mathrm{H} 2020$, and the probability of interacting with another member of the majority group (EU15 member) decreased. Regarding the direct distribution effects between Member States, driven by the two programs, the different nature of the collection, respectively the allocation of funds, is maintained. The funding sources of FP7 and H2O20 are the result of a political decision, and the allocation of funds is based on a competitive, independent process [7]. For this reason, the net distribution effect depends both on the research potential and the scientific quality of a specific country. For FP7, figures show that the net distribution effect is negative for Romania for FP7 [7] and H2020 [8]. In the following lines are presented the comparative results of these two programmes for Romania in the regional context. EC Funding and tender opportunities - Single Electronic Data Interchange Area (SEDIA) provides to all the beneficiaries all the relevant data on $\mathrm{H} 2020$ programme. It is an interactive knowledge platform that offers public access to statistics and data on EU research and innovation. Data were entered in a Microsoff ${ }^{\circledR}$ Excel $^{\circledR}$ spreadsheet and processed using the above-mentioned program. Romania is compared to the 12 former communist states that have undergone in the same way the process of transition to the market economy: Romania, Bulgaria, Czech Republic, Hungary, Finland, Croatia, Latvia, Lithuania, Estonia, Poland, Slovakia, and Slovenia.

\section{FP7 AND H2020 IN THE FORMER EUROPEAN COMMUNISTS COUNTRIES}

Within H2020 programme, up to $28^{\text {th }}$ of March 2020, the European Commission funded 27330 projects that sum a total EU contribution of 50.83 billion euro, the total cost of all these grants being 63,97 billion euro. Romania participated in 787 projects, representing $2.88 \%$ of $\mathrm{H} 2020$, the total number of participations being 1192 , representing $0.89 \%$ of $\mathrm{H} 2020$ participations, with 451 unique participants. Participations of EU 12 countries in H2020 and FP 7 is presented in figure 1.

Figure 1 shows that 7 out of 12 countries registered an increase of participations in $\mathrm{H} 2020$ compared to FP7, among these countries being Romania which saw an increase of $9.15 \%$. The cumulative weight of the total number of EU 12 participants rises from $9.58 \%$ to $9.67 \%$, but still remains below the most performing country, Germany, $13.5 \%$ and respectively $11.9 \%$. Finland and Poland are in the first places in terms of number of participations, given that the population of Poland is more than seven times larger. Still, the ranking does not change significantly between FP7 and $\mathrm{H} 2020$.

Regarding the Net EU Contribution, figure 2 shows that all the analysed countries registered increases, the smallest of these increases being in Hungary, of about $0.38 \%$ and the largest in Estonia of about $98.65 \%$

In total EU Contribution, the analysed countries rise from $5.91 \%$ to $6.88 \%$, but, cumulated, remain below the percent of the most performing country: Germany, that reached more than $15 \%$ in both programmes.

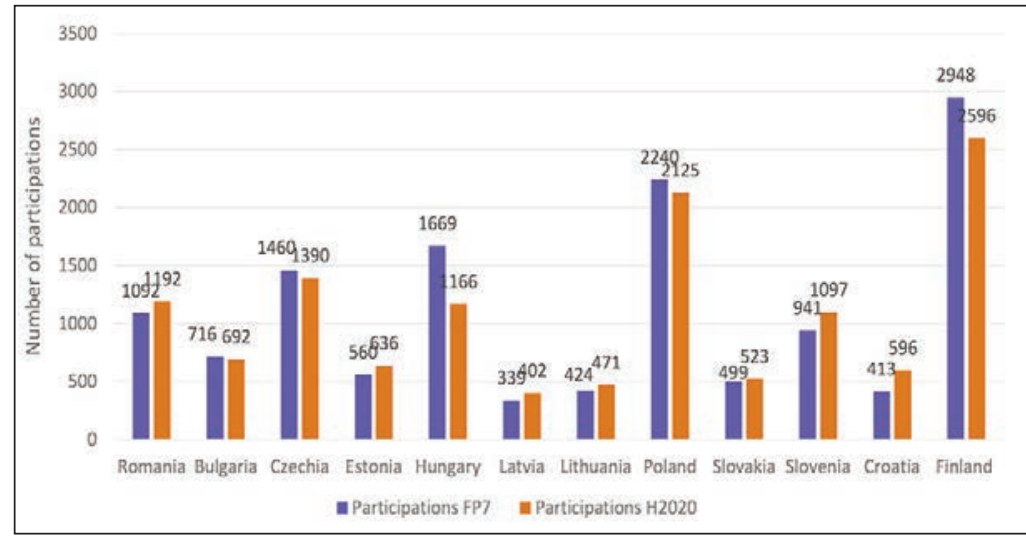

Fig. 1. EU 12 Participations in FP7 and H2O20 [9] 


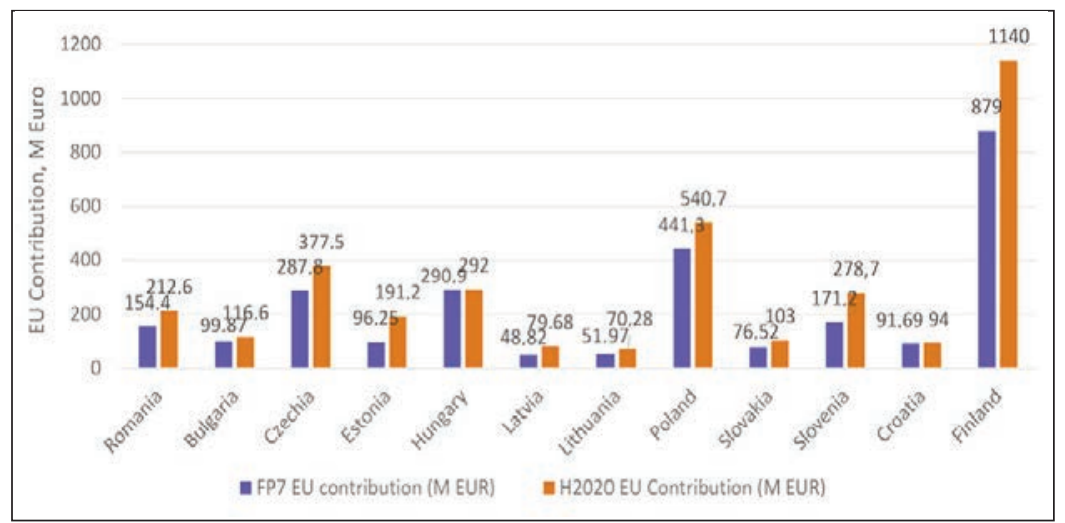

Fig. 2. FP7 and H2020 EU Contribution (M Euro) for EU12 [9]

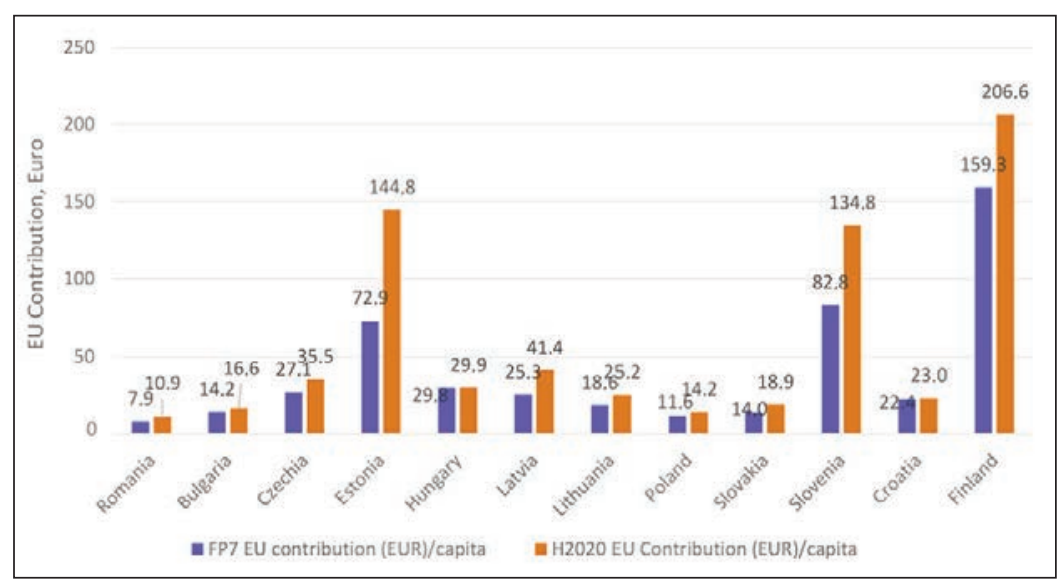

Fig. 3. EU Contribution/Inhabitant: FP7 and H2020 [9-10]

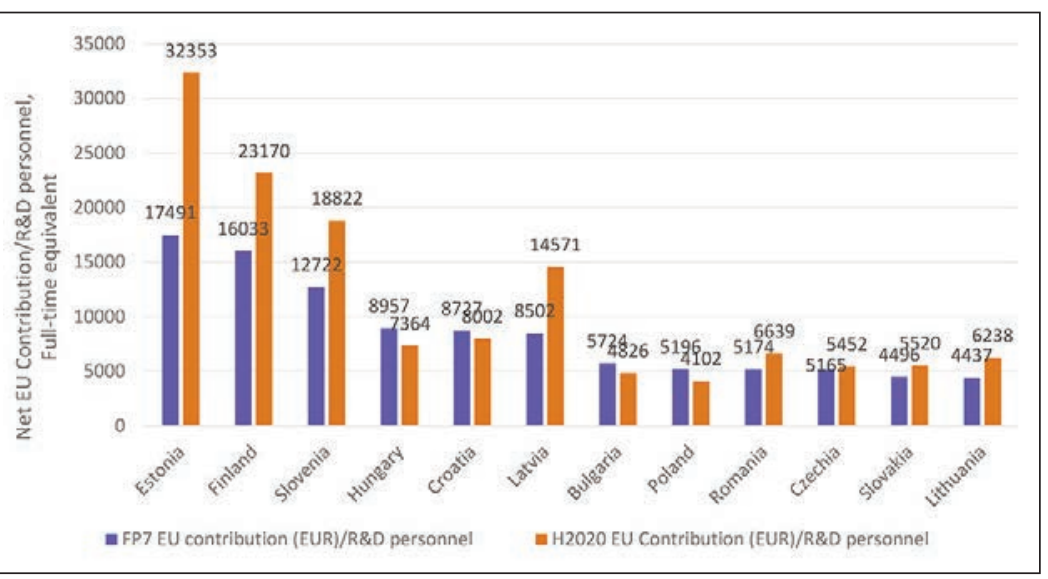

Fig. 4. Net EU Contribution/R\&D personnel, Full-time, FP7 and $\mathrm{H} 2020$ [9-11]

Romania also registered an important increase of the financing, of $37.69 \%$, above the regional average of approx. 30\%. EU 12 ranking changes if the EU contribution per inhabitant is clearly determined, as shown in figure 3.

It can be seen that Romania occupies the last place in the EU12, both for FP7, and H2020. The first three places are occupied by Finland, Estonia and Slovenia for both programmes. Between the FP7 and $\mathrm{H} 2020$ the ranking does not change much: Estonia, Latvia, Lithuania and Slovakia advance one place, and Hungary, Croatia and Bulgaria go down one place. Poland and Romania remain in the last two places. Regarding the productivity of the research activity measured by the researchers' ability to attract funding within the two analysed programs, the situation is presented in figure 4.

Figure 4 shows that the first three countries remain, in order, Estonia, Finland and Slovenia. Three countries go down significantly in this rank, cu 5, respectively 4 positions: Lithuania, Bulgaria and Poland, while Romania, Slovakia and Latvia are going up two places. On average, the productivity increases by $33.6 \%$, so for $\mathrm{H} 2020$ the average exceeds Germany. The gaps between the EU12 countries are very large,

with Estonia having this indicator 7.88 times larger than Poland. Thus, within the EU12 two groups of countries are distinguished: on one hand Estonia, Finland, Slovenia and Latvia with an equal or higher performance than Western Europe and the rest of the countries, with a lower performance.

\section{CONCLUSIONS}

The objective of this paper was to highlight the Romanian position in the former EU communist countries from the perspective of participating in the FP7 and H2020 research framework programmes. EU12 countries saw an increase of about $16.35 \%$ in participation in $\mathrm{H} 2020$, compared to FP7 in terms of net EU contribution. The number of participations increased less, the total share of these countries being $9.67 \%$ in $\mathrm{H} 2020$, compared with $9.58 \%$ in FP7, which confirms the conclusions of previous studies, namely that the new member states are less competitive compared to EU15. In the analysed group there are large gaps in terms of the efficiency of the use of human resources. Romania has improved its positions in the rankings, as follows: from the point of view of the number of participations, it moved from position 5 to $4^{\text {th }}$ position, and for the net EU contribution per R\&D personnel won two positions - from $9^{\text {th }}$ place to $7^{\text {th }}$ place. However, it remains on the $6^{\text {th }}$ position from the point of view of EU contribution and on the last place in Europe on the indicator of EU contribution per inhabitant. 


\section{ACKNOWLEDGEMENT}

This research was supported financially by the project CNFIS-FDI-2018-0582 - Supporting Excellence Research within The Bucharest University of Economic Studies in the context of the principles of sustainable development and open research. 6. Supporting field research excellence in universities Beneficiary: The Bucharest University of Economic Studies.

\title{
REFERENCES
}

[1] Vinnova, FP7 and Horizon 2020 - a comparative study of the support services in the Nordic countries, VINNOVA - Swedish Governmental Agency for Innovation Systems/Verket för Innovationssystem, 2013, Available at: https://www.vinnova.se/contentassets/7d05ced949354fe5bdc670f08d7b1a6a/va_13_16.pdf [Accessed February 2020]

[2] Vught, van F., The EU Innovation Agenda: Challenges for European Higher Education and Research, In: Higher Education Management and Policy, 2009, 21, 2, 1-22

[3] Rauch, M., Sommer-Ulrich, J., Participation of the Central and Eastern European EU Member States in the 7th Framework Programme: Analysis, Evaluation, Recommendations, Fraunhofer MOEZ Institute, 2012, Available at: http://www.moez.fraunhofer.de/en/publikationen/jcr:content/contentPar/textblockwithpics/linklistPar/download/file. res/MOEZ_summary_final.pdf [Accessed February 2020]

[4] Galsworthy, M., McKee, M., Europe's 'Horizon 2020' science funding programme: how is it shaping up?, In: Journal of Health Services Research \&Policy, 18(3) 182-185, Available at: https://www.ncbi.nlm.nih.gov/pmc/articles/ PMC4107840/pdf/10.1177-1355819613476017.pdf [Accessed February 2020]

[5] Moagar-Poladian, S., Folea, V., Paunica, M., Competitiveness of EU Member States in Attracting EU Funding for Research and Innovation, In: Romanian 150 Journal of Economic Forecasting, Institute for Economic Forecasting, 2017, 2, 150-167, Available at: https://ideas.repec.org/a/rir/romjef/vy2017i2p150-167.html [Accessed February 2020]

[6] Ukrainski, K., Kanep, H., Kirs, M., Karo E., Segregation of EU13 Countries in EU Framework Programmes Illuminates Important Challenges for Cohesion Policy, In: CeSifo Forum 19, 2018, 1, Available at: https://www.cesifo.org/DocDL/CESifo-Forum-2018-1-Ukrainski-EU-Cohesion-policy-march.pdf [Accessed February 2020]

[7] Fisch, P., Monetary (re-)distribution effects of FP7, In: Think Pieces, 2015, 2, Available at: https://www.peterfisch.eu/european-research-policy/think-pieces/2-2015-distribution-effects/ [Accessed February 2020]

[8] Fisch, P., Monetary (re-)distribution effects of Horizon 2020 - An updated analysis (June 2017), In: Think Pieces, 2015, 2, Available at: https://www.peter-fisch.eu/european-research-policy/think-pieces/2-2017-distribution-2017/ [Accessed February 2020]

[9] European Commission, Horizon dashboard, Available at: https://ec.europa.eu/info/funding-tenders/opportunities/ portal/screen/opportunities/horizon-dashboard [Accessed 28 th of March 2020]

[10] World Bank, World Bank open data, Available at: https://data.worldbank.org/ [Accessed $28^{\text {th }}$ of March 2020]

[11] European Commission, Eurostat, Available at: https://ec.europa.eu/eurostat/databrowser/view/tsc00003/default/ table?lang=en [Accessed $28^{\text {th }}$ of March 2020]

Authors:

\section{MONICA DUDIAN ${ }^{1}$, DANIELA VASILE ${ }^{2}$, MARGARETA STELA FLORESCU ${ }^{1}$}

${ }^{1}$ Bucharest University of Economic Studies, 6 Piata Romana, 010374, Bucharest, Romania email: margareta.florescu@ari.ase.ro

${ }^{2}$ National Institute for Research and Development on Marine Geology and Geo-ecology - GeoEcoMar, 23-25 Dimitrie Onciul Street, 024053, Bucharest, Romania email: danabiro@yahoo.com

\section{Corresponding author:}

\author{
MONICA DUDIAN
}

email: monica.dudian@economie.ase.ro 